\title{
Phytochemical and Antifungal Evaluation of Plant Extracts against Alternaria brassicicola (Schw.) Wiltshire Causing Black Leaf Spot of Cauliflower
}

\author{
Heipormi Papang* and R.K. Tombisana Devi \\ Department of Plant Pathology, College of Post Graduate Studies, Central Agricultural \\ University, Umiam-793103, Meghalaya, India \\ *Corresponding author
}

\section{A B S T R A C T}

\section{Keywords}

Phytochemical,

Plant extracts,

Alternaria

brassicicola,

Concentrations,

Cauliflower, Per

cent inhibition

Article Info

Accepted:

04 June 2018

Available Online:

10 July 2018
The present study was conducted to detect the presence of phytochemicals in plant extracts pertaining to Meghalaya and their efficacy against Alternaria brassicicola, a causal agent of black leaf spot of cauliflower. Phytochemical screening of plant extracts studied showed that winged prickly ash and ginger had almost all the phytochemicals tested but least phytochemicals was observed in black pepper. Phytochemicals such as alkaloids and flavonoids were presence in almost all plant extracts. Aqueous extract of pitcher plant gave $100 \%$ inhibition of growth of pathogen at 10 and $15 \%$ concentrations followed by garlic clove extract $(83.78 \%)$ and pericarp extract of winged prickly ash $(82.59 \%)$ at $15 \%$ concentration. Winged prickly ash, garlic, ginger, black pepper, sweet flag and pitcher plant showed highly effective against pathogen with increased in concentrations. Though derek, stinging nettle in all concentrations and wild brinjal at 5\% were recorded less than $40 \%$ inhibition but showed a positive correlation between concentration and percent inhibition on growth of pathogen.

\section{Introduction}

Cauliflower (Brassica oleracea L. var. botrytis) is an important member of Cole crops which belongs to genus Brassica and family Brassicaceae. It is rich in minerals, nutrients and vitamins which makes it good for health. Besides thiamin, riboflavin, niacin, potassium, magnesium, iron and protein it has fairly high in vitamins $\mathrm{A}$ and $\mathrm{C}$ and folic acid content (Yamaguchi, 1983).
India is the second largest country next to China in cauliflower production in area (452000 ha) and production (8499000 MT) (Anonymous, 2017). A cruciferous crop including cauliflower is prone to attack by several insects and diseases that can significantly reduce yield and quality of crop. Many fungal, bacterial and viral plant pathogens attack the crop and amongst them fungal disease black leaf spot caused by two species of Alternaria are the most destructive one causing qualitative as well as quantitative 
losses and are becoming a serious problem. However the disease caused by A. brassicicola is becoming more serious in the state.

Majority of the pesticides act like blunt weapons that kill organisms, in addition to target pests. Many of these substances contaminate the environment to a great extent. They can also enter the body of organisms, bio accumulate in the food chains and consequently affect the human health. There exists a direct relationship between the extent of pesticides used and signs and symptoms of illness due to exposure among farmers (Kishi et al., 1995). The resistance of microorganisms against antimicrobial drugs is a major problem of recent times, which is increasing day by day (Cohen, 2000; Kumar et al., 2013).

Plant extracts represent a rich source of antimicrobial agents and have been used by Indian system of medicine in preventive, promotive and curative applications. Extracts of various plant parts are found to be very effective against pathogenic seed borne fungi. Seed borne fungi can be efficiently achieved by using synthetic chemical fungicides but the same cannot be applied to grains for reasons of pesticides toxicity (Harris et al., 2001). Plant-derived compounds such as hydroquinones and naphthoquinones (lapachol, juglone), sesquiterpenes (cinnamodial, capsidiol) and alkaloids (berberine) have shown diverse activities as antimicrobial and antifungal. An advantage to the approach of using ethnobotanical leads to identify compounds with antimicrobial activity (Galvan et al., 2008). Medicinal plants are considered as the greatest pharmaceutical stores existing on the earth as they can produce eternal secondary phytochemicals having bioactive properties. These phytochemicals work efficiently to cure various diseases and illnesses since ancient times (Abdallah, 2011)
Therefore, in the present investigation major emphasis was to detect the presence of phytochemicals and to evaluate the efficacy of plant extracts which is an alternative approach to fungicides.

\section{Materials and Methods}

\section{Isolation, identification and maintenance of pathogen}

Leaf spot of cauliflower showing typical symptoms were collected from farmers' field of Ri-Bhoi district in Meghalaya. The leaves were then brought to the laboratory and microscopically examined to confirm the presence of the pathogen. After confirming for the presence of fungal spores, isolation was done by tissue segment method (Rangaswami, 1958) on Potato Dextrose Agar (PDA) medium. Cauliflower leaves showing characteristic of black leaf spot symptom were cut into small pieces of $2 \mathrm{~mm}$ along with some healthy portions. The pieces were then surface sterilized with $1 \% \mathrm{NaOCl}$ solution for one minute followed by serial washing in sterile distilled water thrice and blot dried with sterilized filter paper. The sterilized leaf bits were then aseptically transferred into $9 \mathrm{~cm}$ Petri dishes containing sterilized PDA medium and incubated at $27 \pm 1^{\circ} \mathrm{C}$. The fungus was purified by hyphal tip cut method. Culture was compared with the original description of the fungal pathogen and it was identified as $A$. brassicicola. The purified culture was maintained on PDA slants at $4^{\circ} \mathrm{C}$ in refrigerator.

\section{Collection of plant materials}

The fresh plant materials of winged prickly ash (Zanthoxylum khasianum), wild brinjal (Solanum xanthocarpum), garlic (Allium sativum), ginger (Zingiber officinale), black pepper (Piper nigrum), sweet flag (Acorus calamus), derek (Melia azadirach) and pitcher 
plant (Nepenthes khasiana) were collected from different places of Meghalaya, India and were used for the purpose of phytochemical analysis and its efficacy against $A$. brassicicola.

\section{Preparation of plant extracts}

The collected plants were surface sterilized with $1 \%$ sodium hypochlorite and then washed 3-4 times with distilled water followed by shade drying and the plant parts were then crushed into powder form and stored in polythene bags for further used.

\section{Phytochemical analysis}

Plant extracts was carried out for detection of phytochemical such as saponins, tannins, alkaloids, glycosides, flavonoids and phenol. The following test conducted was as follows:

Test for saponins: In this test $0.5 \mathrm{gm}$ of extract was added in $10 \mathrm{ml}$ of water, shaken for few minutes. Formations of frothing which persisted for 60-120 seconds, showed presence of saponins (Mojab et al.,2003).

Test for tannins: About $0.5 \mathrm{~g}$ of the dried powdered samples were boiled in $20 \mathrm{ml}$ distilled water in a test tube and then filtered. A few drops of $0.1 \%$ ferric chloride were added to the filtrate and was observed for blue-black or a brownish green coloration (Rashid et al., 2013).

Test for alkaloids: A $0.2 \mathrm{~g}$ of the selected plant samples were added in each test tube and $3 \mathrm{ml}$ of hexane were mixed in it, shaken well and filtered. A $5 \mathrm{ml}$ of $2 \% \mathrm{HCl}$ was then poured in a test tube having the mixture of plant extract and hexane. The test tube having the mixture was heated, filtered and few drops of picric acid in a mixture were added. Formation of yellow color precipitate indicates the presence of alkaloids. (Wadood et al., 2013).
Test for glycosides: A $5 \mathrm{ml}$ of dilute $\mathrm{HCl}$ was added in $0.5 \mathrm{gm}$ of extract and boiled on water bath for 10 minutes. Solution was filtered and filtrate was extracted with benzene and mixed with ammonia solution. Red color was obtained in ammonia layer that indicated the presence of glycosides (Evans and Trease, 2008).

Test for phenol: About $0.5 \mathrm{~g}$ of dried powdered samples of each plant extract was dissolved in $2 \mathrm{ml}$ of distilled water and $1 \mathrm{ml}$ of iodine solution was added and observed for coloration. Formation of transient red color indicates the presence of phenol (Ansari, 2006).

Test for flavonoids: A $0.5 \mathrm{~g}$ of each selected plant extract was added in a test tube and 10 $\mathrm{ml}$ of distill water. $5 \mathrm{ml}$ of dilute ammonia solution were added to a portion of the aqueous filtrate of each plant extract followed by addition of $1 \mathrm{ml}$ concentrated $\mathrm{H}_{2} \mathrm{SO}_{4}$. Indication of yellow color shows the presence of flavonoids in each extract (Wadood et al., 2013).

\section{Efficacy of plant extracts against Alternaria brassicicola}

Plant extracts were evaluated for their antifungal effects on growth of A. brassicicola by poisoned food technique (Nene and Thapliyal, 1979). Aqueous plant extract was prepared by taking $100 \mathrm{gms}$ of the desired plant material and washed them twice in running tap water and allowed them to dry for sometimes. Then they were subjected to washing again thrice with sterile distilled water and crush in a surface sterilized pestle and mortar by adding equal amount of sterile distilled water. After proper grinding, the extracts were squeezed through three layers of muslin cloth to extract the juice. The juices were then filtered it through a Whatman No. 42 filter paper. The filtrate was centrifuge at $15000 \mathrm{rpm}$ for $10 \mathrm{mins}$. The supernatant was 
then sterilized finally through bacteria proof membrane syringe filter $(0.22 \mu)$ under laminar air flow. The final clear extracts prepared were the standard plant extracts of $100 \%$ concentration. These were evaluated at three different concentrations viz., 5, 10 and $15 \%$ by adding required amount of extract to PDA medium. The plates containing PDA without any plant extract were maintained as untreated control. After solidification of media, all the plates were aseptically inoculated by placing in the centre a five mm mycelial disc obtained from a four days old actively growing pure culture and then incubated at $27 \pm 1^{\circ} \mathrm{C}$. Each treatment was replicated thrice.

The tested fungus was recorded treatmentwise till mycelial growth gave fully covered in the untreated control plate. Percentage inhibition (I) of the pathogen was calculated by following the formula described by Vincent (1927).

$$
\mathrm{I}=\frac{\mathrm{C}-\mathrm{T}}{\mathrm{T}} \times 100
$$

Where,

$\mathrm{I}=$ Per cent inhibition of mycelial growth,
$\mathrm{C}=$ Growth in control and

$\mathrm{T}=$ Growth in treatment

\section{Results and Discussion}

The result (Table 1) showed the presence of alkaloids and flavonoids in almost all plant extracts. The least detected phytochemical was tannins. The presence of phytochemicals varied from one plant extract to another (Plate $1)$.

The study revealed that all plant extracts showed significant difference in per cent inhibition of radial growth of A. brassicicola. Pitcher plant extract gave a complete inhibition $(100 \%)$ of mycelial growth at both $10 \%$ and $15 \%$ followed by garlic $(83.78 \%)$, winged prickly ash (82.59\%) and sweet flag $(78.15 \%)$ (Table 2). The least per cent inhibition was recorded in stinging nettle $(15.19 \%)$ at $5 \%$ concentration (Figure 1 and Plate 2). Most of the plant extracts showed more than 40 per cent inhibition. There was positive correlation between concentration and growth inhibition percentage in all the plant extracts.

Table.1 Phytochemical analysis of the extracts

\begin{tabular}{|l|c|c|c|c|c|c|c|}
\hline Sl. No. & Plant & saponins & tannins & alkaloids & glycosides & flavonoids & phenol \\
\hline $\mathbf{1}$ & $\begin{array}{c}\text { Winged } \\
\text { prickly ash }\end{array}$ & + & - & + & + & + & + \\
\hline $\mathbf{2}$ & Wild brinjal & - & - & + & + & + & + \\
\hline $\mathbf{3}$ & Garlic & - & - & + & + & + & + \\
\hline $\mathbf{4}$ & Ginger & + & - & + & + & + & + \\
\hline $\mathbf{5}$ & Black pepper & - & - & - & + & + & + \\
\hline $\mathbf{6}$ & Sweet flag & + & - & + & + & + & - \\
\hline $\mathbf{7}$ & Derek & + & + & + & - & + & - \\
\hline $\mathbf{8}$ & Pitcher plant & + & + & + & - & + & - \\
\hline $\mathbf{9}$ & $\begin{array}{c}\text { Stinging } \\
\text { nettle }\end{array}$ & + & + & - & - & - & + \\
\hline
\end{tabular}

$(+)$ indicates presence of phytochemicals

(-) indicates absence of phytochemicals 
Int.J.Curr.Microbiol.App.Sci (2018) 7(7): 306-315

Table.2 In vitro efficacy of plant extracts against the growth of A. brassicicola

\begin{tabular}{|c|c|c|c|c|c|c|c|}
\hline \multirow{2}{*}{$\begin{array}{l}\text { SI. } \\
\text { No. }\end{array}$} & \multirow[t]{2}{*}{ Treatments } & \multicolumn{3}{|c|}{ Growth $(\mathbf{c m})^{*}$} & \multicolumn{3}{|c|}{ Per cent inhibition over control } \\
\hline & & $5 \%$ & $10 \%$ & $15 \%$ & $5 \%$ & $10 \%$ & $15 \%$ \\
\hline 1 & $\begin{array}{l}\text { Winged } \\
\text { prickly ash }\end{array}$ & $\begin{array}{c}3.53 \pm 0.09^{\mathrm{t}} \\
(2.01)\end{array}$ & $\begin{array}{c}3.03 \pm 0.12^{\mathrm{tg}} \\
(1.88)\end{array}$ & $\begin{array}{c}1.57 \pm 0.12^{\mathrm{f}} \\
(1.44)\end{array}$ & $\begin{array}{c}60.74 \pm 0.98^{\mathrm{b}} \\
(51.20)\end{array}$ & $\begin{array}{c}66.30 \pm 1.34^{\mathrm{c}} \\
\quad(54.52)\end{array}$ & $\begin{array}{c}82.59 \pm 1.34^{\mathrm{b}} \\
\quad(65.37)\end{array}$ \\
\hline 2 & Wild brinjal & $\begin{array}{c}5.47 \pm 0.03^{\mathrm{d}} \\
(2.44)\end{array}$ & $\begin{array}{c}5.30 \pm 0.12^{\mathrm{d}} \\
(2.41)\end{array}$ & $\begin{array}{c}3.30 \pm 0.15^{\mathrm{c}} \\
(1.95)\end{array}$ & $\begin{array}{c}39.26 \pm 0.37^{\mathrm{d}} \\
(38.80)\end{array}$ & $\begin{array}{c}41.11 \pm 1.28^{\mathrm{e}} \\
\quad(39.88)\end{array}$ & $\begin{array}{l}63.33 \pm 1.70^{\mathrm{e}} \\
\quad(52.74)\end{array}$ \\
\hline 3 & Garlic & $\begin{array}{c}1.70 \pm 0.12^{\mathrm{g}} \\
(1.48)\end{array}$ & $\begin{array}{l}1.62 \pm 0.10^{\mathrm{h}} \\
(1.45)\end{array}$ & $\begin{array}{c}1.46 \pm 0.11^{\mathrm{f}} \\
(1.40)\end{array}$ & $\begin{array}{c}81.11 \pm 1.28^{\mathrm{a}} \\
\quad(64.27)\end{array}$ & $\begin{array}{c}82.04 \pm 1.13^{\mathrm{b}} \\
(64.94)\end{array}$ & $\begin{array}{c}83.78 \pm 1.19^{b} \\
\quad(66.28)\end{array}$ \\
\hline 4 & Ginger & $\begin{array}{c}3.57 \pm 0.12^{f} \\
(2.02)\end{array}$ & $\begin{array}{c}2.88 \pm 0.11^{\mathrm{g}} \\
(1.84)\end{array}$ & $\begin{array}{c}2.47 \pm 0.12^{\mathrm{d}} \\
(1.72)\end{array}$ & $\begin{array}{c}60.37 \pm 1.34^{\mathrm{b}} \\
(50.99)\end{array}$ & $\begin{array}{c}67.96 \pm 1.21^{\mathrm{c}} \\
(55.54)\end{array}$ & $\begin{array}{c}72.59 \pm 1.34^{\mathrm{d}} \\
\quad(58.44)\end{array}$ \\
\hline 5 & $\begin{array}{l}\text { Black } \\
\text { pepper }\end{array}$ & $\begin{array}{c}4.77 \pm 0.12^{\mathrm{e}} \\
\quad(2.29)\end{array}$ & $\begin{array}{c}3.97 \pm 0.15^{\mathrm{e}} \\
(2.11)\end{array}$ & $\begin{array}{c}3.43 \pm 0.15^{\mathrm{c}} \\
(1.98)\end{array}$ & $\begin{array}{c}47.04 \pm 1.34^{\mathrm{c}} \\
\quad(43.30)\end{array}$ & $\begin{array}{l}55.93 \pm 1.61^{\mathrm{d}} \\
\quad(48.41)\end{array}$ & $\begin{array}{c}61.85 \pm 1.61^{\mathrm{e}} \\
\quad(51.86)\end{array}$ \\
\hline 6 & Sweet flag & $\begin{array}{c}3.53 \pm 0.03^{\mathrm{f}} \\
(2.01)\end{array}$ & $\begin{array}{c}3.17 \pm 0.09^{f} \\
(1.91)\end{array}$ & $\begin{array}{c}1.97 \pm 0.22^{\mathrm{e}} \\
(1.57)\end{array}$ & $\begin{array}{c}60.74 \pm 0.37^{\mathrm{b}} \\
(51.20)\end{array}$ & $\begin{array}{c}64.81 \pm 0.98^{c} \\
\quad(53.62)\end{array}$ & $\begin{array}{c}78.15 \pm 2.43^{\mathrm{c}} \\
\quad(62.19)\end{array}$ \\
\hline 7 & Derek & $\begin{array}{c}6.53 \pm 0.09^{\mathrm{c}} \\
(2.65)\end{array}$ & $\begin{array}{c}6.20 \pm 0.12^{\mathrm{c}} \\
(2.59)\end{array}$ & $\begin{array}{c}5.67 \pm 0.13^{b} \\
(2.48)\end{array}$ & $\begin{array}{c}27.41 \pm 0.98^{\mathrm{e}} \\
\quad(31.57)\end{array}$ & $\begin{array}{c}31.11 \pm 1.28^{f} \\
\quad(33.89)\end{array}$ & $\begin{array}{c}37.04 \pm 1.48^{f} \\
(37.48)\end{array}$ \\
\hline 8 & $\begin{array}{l}\text { Pitcher } \\
\text { plant }\end{array}$ & $\begin{array}{c}1.54 \pm 0.18^{\mathrm{g}} \\
(1.43)\end{array}$ & $\begin{array}{l}0.00 \pm 0.00^{i} \\
(0.71)\end{array}$ & $\begin{array}{c}0.00 \pm 0.00^{\mathrm{g}} \\
(0.71)\end{array}$ & $\begin{array}{c}82.85 \pm 1.99^{\mathrm{a}} \\
(65.60)\end{array}$ & $\begin{array}{c}100.00 \pm 0.00^{\mathrm{a}} \\
\quad(89.47)\end{array}$ & $\begin{array}{c}100.00 \pm 0.00^{\mathrm{a}} \\
\quad(89.48)\end{array}$ \\
\hline 9 & $\begin{array}{l}\text { Stinging } \\
\text { nettle }\end{array}$ & $\begin{array}{c}7.63 \pm 0.09^{b} \\
(2.85)\end{array}$ & $\begin{array}{c}6.67 \pm 0.12^{\mathrm{b}} \\
(2.68)\end{array}$ & $\begin{array}{c}5.73 \pm 0.07^{b} \\
(2.50)\end{array}$ & $\begin{array}{c}15.19 \pm 0.98^{f} \\
(22.92)\end{array}$ & $\begin{array}{l}25.93 \pm 1.34^{\mathrm{g}} \\
\quad(30.59)\end{array}$ & $\begin{array}{c}36.30 \pm 0.74^{\mathrm{f}} \\
(37.05)\end{array}$ \\
\hline 10 & Control & $\begin{array}{c}9.00 \pm 0.00^{\mathrm{a}} \\
(3.08)\end{array}$ & $\begin{array}{c}9.00 \pm 0.00^{\mathrm{a}} \\
(3.08)\end{array}$ & $\begin{array}{c}9.00 \pm 0.00^{\mathrm{a}} \\
(3.08)\end{array}$ & $\begin{array}{c}0.00 \pm 0.00^{\mathrm{g}} \\
(0.52)\end{array}$ & $\begin{array}{c}0.00 \pm 0.00^{\mathrm{h}} \\
(0.52)\end{array}$ & $\begin{array}{c}0.00 \pm 0.00^{\mathrm{g}} \\
(0.52)\end{array}$ \\
\hline & SE(m) & 0.03 & 0.03 & 0.04 & 0.76 & 0.71 & 0.91 \\
\hline & $D(p=0.05)$ & 0.08 & 0.08 & 0.11 & 2.24 & 2.11 & 2.68 \\
\hline
\end{tabular}


Figure.1 Bar diagram showing the per cent inhibition of plant extracts against growth of $A$. brassicicola

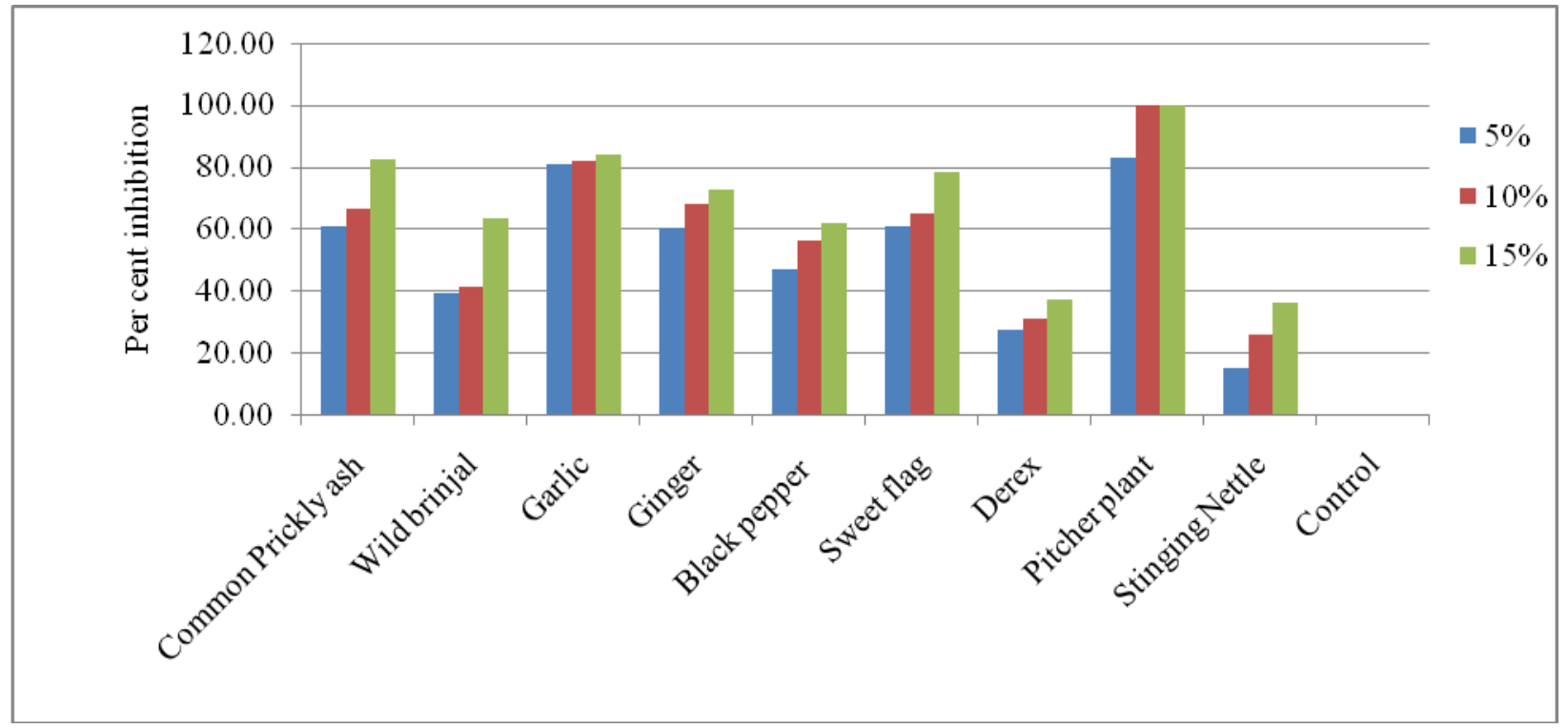

Plate.1 Phytochemical analysis of various plant extracts

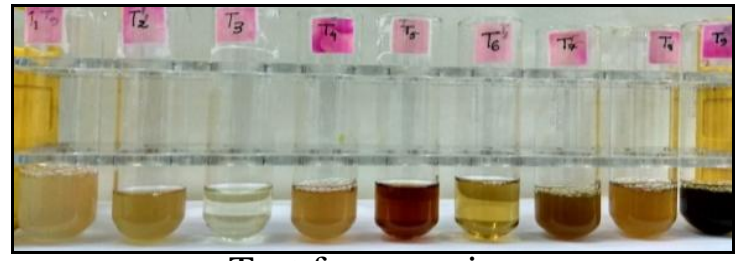

Test for saponins

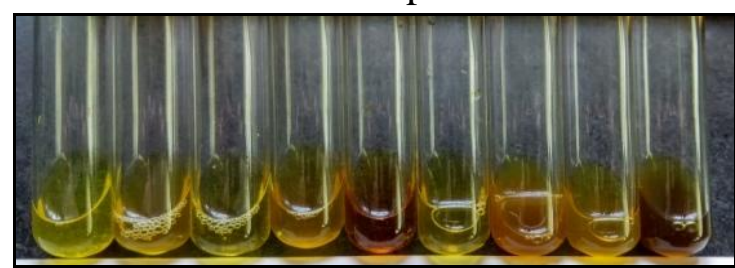

Test for alkaloids

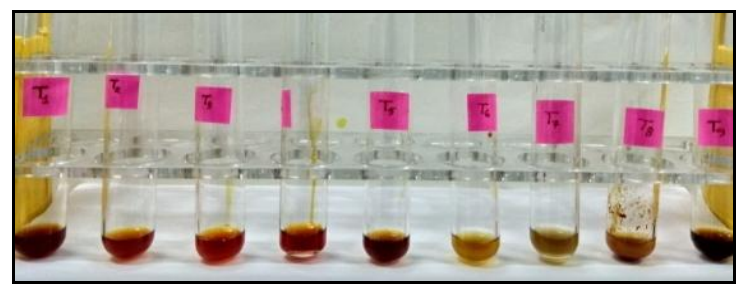

Test for phenol

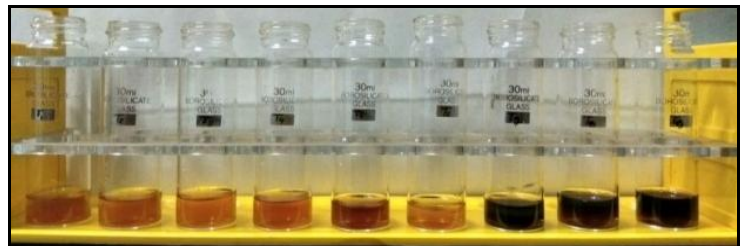

Test for tannins

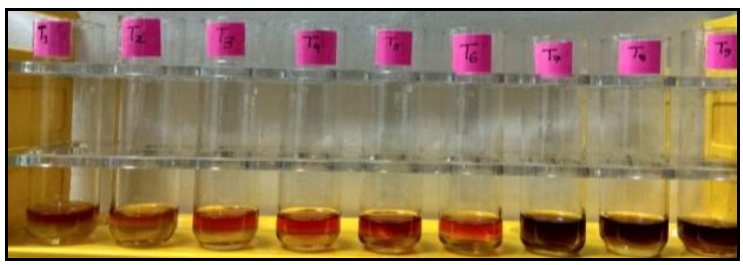

Test for glycosides

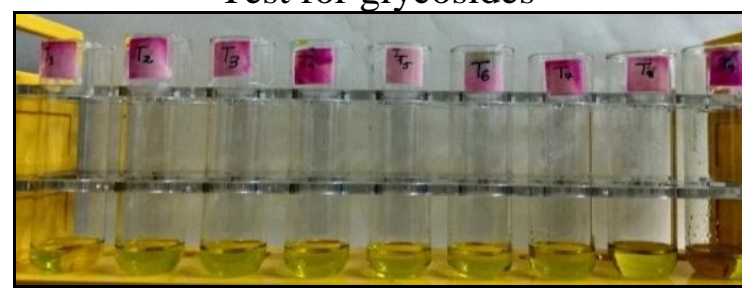

Test for flavonoids 
Plate.2 Efficacy of plant extracts against A. brassicicola
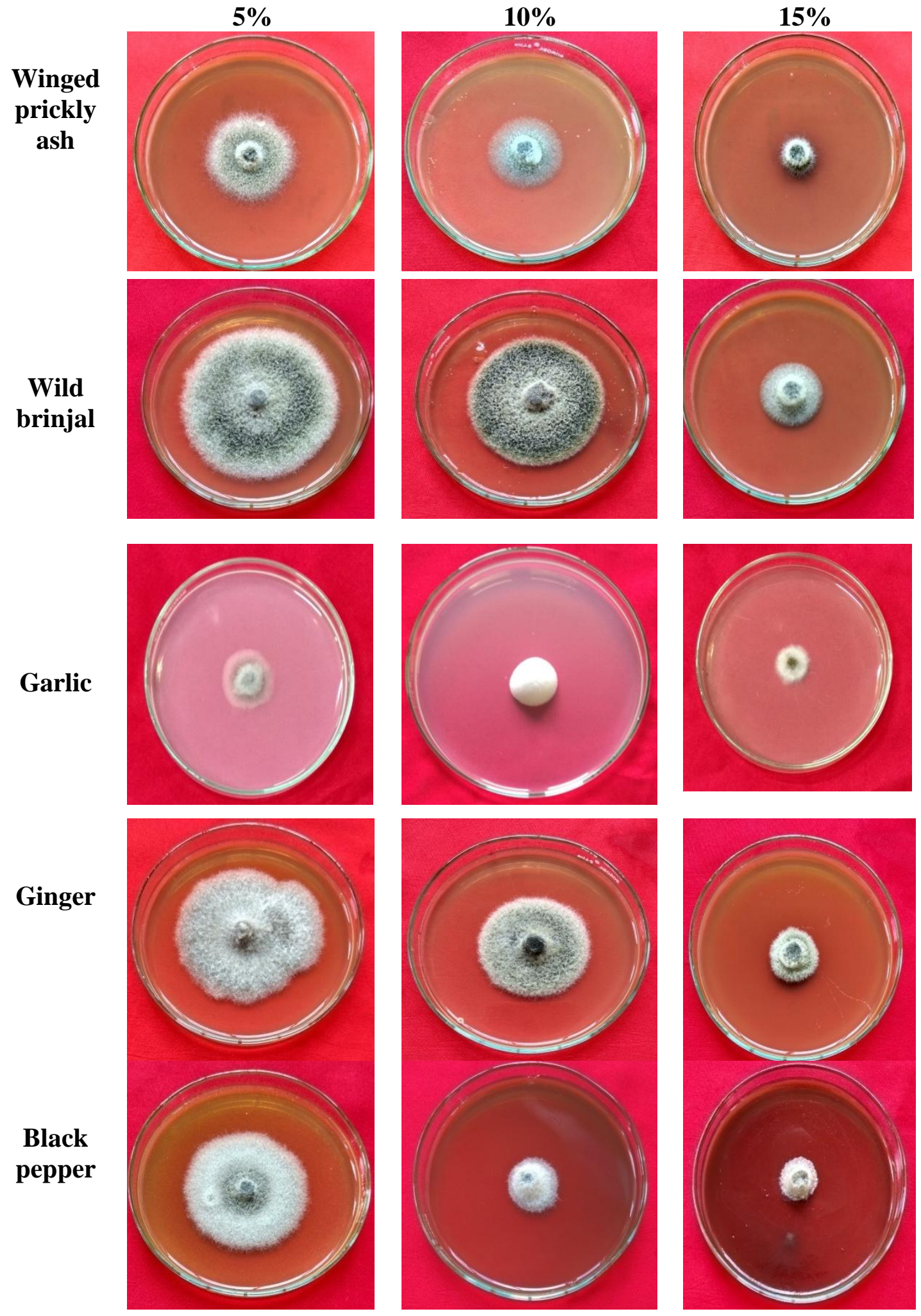

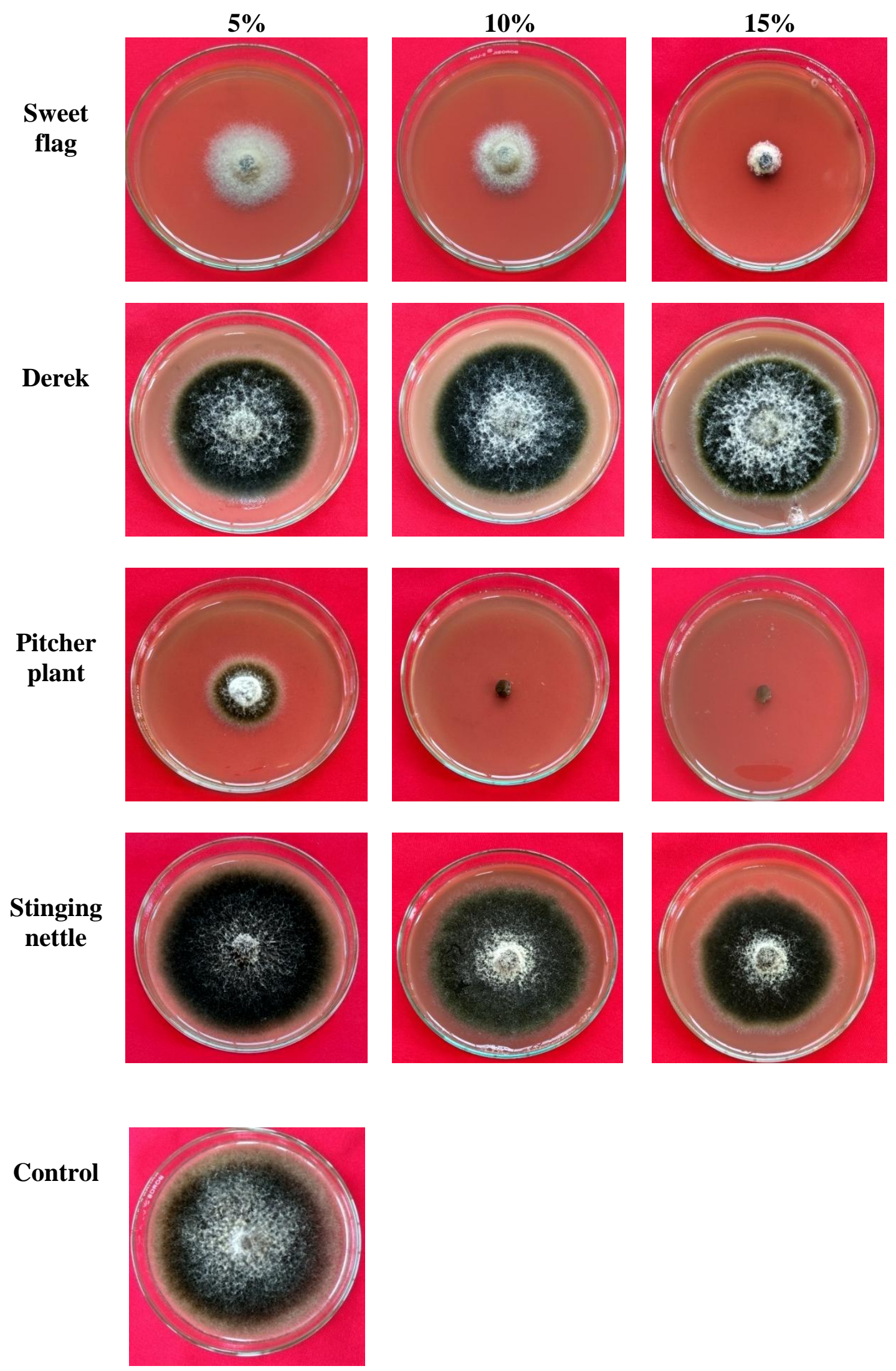
Among all the phytochemical tested, alkaloids and flavonoids were found presence in almost all plant extracts viz., winged prickly ash, wild brinjal, garlic, ginger, black pepper, and sweet flag. The least detected phytochemical was tannins which presence only in derek, pitcher plant and stinging nettle. The phytochemical screening of nine plants extract studied showed that winged prickly and ginger had almost all these phytochemicals tested viz., saponins, alkaloids, glycosides, flavonoids and phenol but least phytochemicals was observed in black pepper and stinging nettle. Imam et al., (2013) reported the presence of glycosides, flavonoids, saponins, tannins, polyphenolic compounds in sweet flag which is similar to the present findings.

Among the nine plant extracts evaluated at three different concentrations, pitcher plant extract gave $100 \%$ inhibition of growth at 10 and $15 \%$ concentrations followed by garlic clove extract (83.78\%) and pericarp extract of winged prickly ash (82.59\%) each at $15 \%$ concentration. Winged prickly ash, garlic, ginger, black pepper, sweet flag and pitcher plant showed highly effective against $A$. brassicicola with increased in concentrations. However, derek, stinging nettle at all concentrations and wild brinjal at 5\% were recorded less than $40 \%$ inhibition of growth of pathogen. The present finding is supported by findings of Sowjanya and Charay, (2012) who reported that Allium sativum was found to be most effective almost completely checking the mycelia growth at $10 \%$ concentration showing $83.09 \%$ inhibition against Microsporum gypseum. Similarly Shenoi et al., (1998) evaluated that the plant extracts were less effective at lower concentrations but there was a positive correlation between concentration and growth inhibition percentage of Alternaria alternata causing brown spot of disease of tobacco. Mohammad et al., also (2015) also reported that the potent inhibition of aqueous extract of Melia azedarach, Cassia siamea and Morraya koenigii on the growth of Aspergillus niger is due to presence of phenolics, alkaloids, flavonoids and tannins. It was also reported that these bioactive molecules give resistance to plants against pests and pathogenic infections by Dixon (2011).

In conclusion, phytochemical analysis found that almost all plant extracts revealed the presence of alkaloids, flavonoids, phenols, glycosides, saponins and tannins. Aqueous fresh extracts of pitcher plant at all concentrations showed maximum per cent inhibition of $A$. brassicicola. Out of Nine plant extracts evaluated, seven of them showed highly effective in inhibiting the growth of the pathogen. Plant extract could be recommended as one of the component into IDM programmes.

\section{References}

Abdallah, E.M., 2011. Plants: An alternative source for antimicrobials. J. Appl. Pharmaceutical Sci. 1(6): 16-20.

Anonymous, 2017. Indian Horticulture Database

Ansari, S.H., 2006. Essentials of pharmacognosy. Birla Publications Pvt. ltd. West Rohtas Nagar, Shadara, Delhi. $1^{\text {st }}$ edn: 340.

Cohen, M.L., 2000. Changing patterns of infectious disease. Nature. 406(6797): 762-767

Dixon, R.A., 2001. Natural products and plant disease resistance. Nature. 411: 843847.

Evans, W.C. and Trease, G.E. 2008. A text book of Pharmacognosy. Bailliare Tindall and Cassel. $14^{\text {th }}$ ed. p.13.

Galvan, I.J., N. Mir-Rashed, M. Jessulat, M. Atanya and Golshani A, et al., 2008. Antifungal and antioxidant activities of the phytomedicine pipsissewa, 
Chimaphila

Phytochemistry. 69: 738-746.

Harris, C.A., M.J. Renfrew, and Woolridge, M.W. 2001. Assesing the risk of pesticides residues to consumers: recent and future developments. Food add. Contamination. 18: 1124-1129.

Imam, H., Z. Riaz, M. Azhar, G. Sofi and Hussain, A. 2013. Sweet flag (Acorus calamus Linn.): An incredible medicicnal herb. Int. J. of Green Pharm. 7:288-296.

Kishi, M., N. Hirschhorn, M. Djajadisastra, L.N. Satterlee, S. Strowman and Dilts R 1995. Relationship of pesticide spraying to signs and symptoms in Indonesian farmers. Scand. J. Work Environ. Health. 21:124-33.

Kumar, M., K, Nehra and Duhan, J.S. 2013. Phytochemical analysis and antimicrobial efficacy of Leaf extracts of Pithecellobium dulce. Asian J. Pharmaceutical and Clinical Research. 6(1): 70-76.

Mohammad, D., Hisamuddin and Robab, M.I. 2015. In Vitro Studies on Phytochemical Screening of Different Leaf Extracts and Their Antifungal Activity against Seed Borne Pathogen Aspergillus niger. J. Plant Pathol. Microbiol. 6(11):1-5.

Mojab, F., M. Kamalinejad. N. Ghaderi and Vahidipour, H.R. 2003. Phytochemical Screening of some species of Iranian plants. Iranian J. of Pharmaceutical Res. 2. 77-82.

Nene, Y.L., and Thapliyal, P.N. 1979. Evaluation of fungicides. In:
Fungicides in Plant Disease Control. Oxford and IBH Publishing Company, New Delhi, pp. 531-532.

Rangaswami, G., 1958. An agar blocks technique for isolating soil microorganisms with special reference to Pythiaceous fungi. Sci. and Cult. 24: 85.

Rashid, F., N. Sharif, I. Ali, S. Sharif, F.U. Nisa and Naz. S. 2013. Phytochemical analysis and inhibitory activity of ornamental Plant (Bougainvillea spectabilis). Asian J. of Plant Sc. and Res. 3(2):1-5.

Shenoi, M.M., K.K. Murthy, S.S. Sreenivas and Wajid, S.M.A. 1998. In vitro evaluation of botanicals for mycotoxic properties against Alternaria alternata causing brown spot disease of tobacco. Tobbacco Res. 24: 77-81.

Sowjanya, N.C., and Charay, C.M. 2012. Effect of plant extracts on the growth of Microsporum gypseum. J. Pathol. 4(2): 41-44.

Vincent, J.M., 1927. Distortion of fungal hyphae in presence of certain inhibitors. Nature. 159: 850.

Wadood, A., M. Ghufran, S.B. Jamal, M. Naeem, A. Khan, R. Ghaffar and Asnad. 2013. Phytochemical analysis of medicinal Plants occurring in local area of Mardan. Biochem. and Anal. Biochem. 2: 144. doi: 10.4172/21611009.1000144.

Yamaguchi, M., 1983. World vegetables, principles, production and nutritive values. Ellis Horwood Limited Publishers. p. 415.

\section{How to cite this article:}

Heipormi Papang and Tombisana Devi, R.K. 2018. Phytochemical and Antifungal Evaluation of Plant Extracts against Alternaria brassicicola (Schw.) Wiltshire Causing Black Leaf Spot of Cauliflower. Int.J.Curr.Microbiol.App.Sci. 7(07): 306-315. doi: https://doi.org/10.20546/ijcmas.2018.707.037 